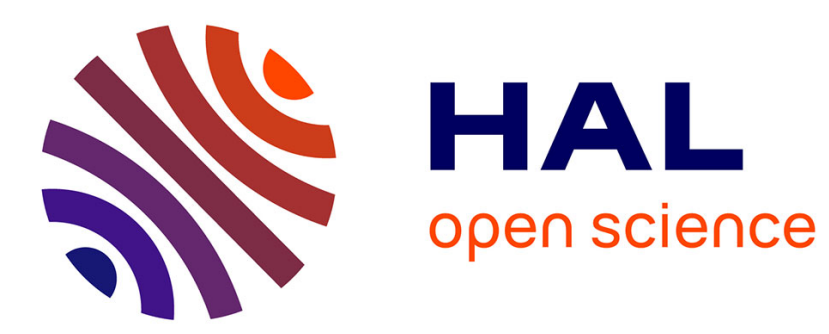

\title{
Liquidity Regulation and Bank Risk
}

Foly Ananou, Dimitris Chronopoulos, Amine Tarazi, John O S Wilson

\section{To cite this version:}

Foly Ananou, Dimitris Chronopoulos, Amine Tarazi, John O S Wilson. Liquidity Regulation and Bank Risk. 2021. hal-03366418

\section{HAL Id: hal-03366418 https://hal.science/hal-03366418}

Preprint submitted on 5 Oct 2021

HAL is a multi-disciplinary open access archive for the deposit and dissemination of scientific research documents, whether they are published or not. The documents may come from teaching and research institutions in France or abroad, or from public or private research centers.
L'archive ouverte pluridisciplinaire HAL, est destinée au dépôt et à la diffusion de documents scientifiques de niveau recherche, publiés ou non, émanant des établissements d'enseignement et de recherche français ou étrangers, des laboratoires publics ou privés. 


\title{
Liquidity Regulation and Bank Risk
}

\author{
Foly Ananou ${ }^{a, 1}$ Dimitris Chronopoulos ${ }^{b}$ Amine Tarazi $^{a, c}$ John O.S. Wilson $^{b}$ \\ a Université de Limoges, LAPE, 5 rue Félix Eboué, 87031 Limoges Cedex 1, France \\ ${ }^{\mathrm{b}}$ University of St Andrews, Centre for Responsible Banking \& Finance, Gateway Building, St Andrews, Fife \\ KY16 9RJ, UK \\ ${ }^{\mathrm{c}}$ Institut Universitaire de France (IUF), 1 rue Descartes, 75231 Paris Cedex 05, France
}

This version: September 23, 2021

Preliminary draft. Not edited. Please do not quote without permission of the authors.

\begin{abstract}
In this paper, we investigate the impact of liquidity requirements on bank risk. We take advantage of the implementation of the Liquidity Balance Rule (LBR) in the Netherlands in 2003 and analyze its impact on bank default risk. The LBR was imposed on Dutch banks only and did not apply to other banks operating elsewhere within the Eurozone. Using this differential regulatory treatment to overcome identification concerns, we find that following the introduction of the LBR, the risk of Dutch banks declined relatively to counterparts not affected by the rule. Concomitantly, despite the lower cost of funding driven by the LBR, the profitability of Dutch banks decreased in comparison with other banks in Europe, as a result of a decrease in income accruing from interest-bearing activities. Our findings also indicate that relatively to unaffected banks, Dutch banks might not have actively tried to offset their loss in interest income by increasing interest rates of loans. However, better financing conditions allowed Dutch banks to increase the shares of deposits and capital on the liability side of their balance sheets.
\end{abstract}

JEL Classification: G21, G28

Keywords Banking, liquidity regulation, Netherlands, propensity score matching, quasi-natural experiment, risk, stability.

\footnotetext{
${ }^{1}$ Corresponding author. Tel: +33555149251.

Email addresses: foly.ananou@etu.unilim.fr (F. Ananou), dc45@st-andrews.ac.uk (D. Chronopoulos), amine.tarazi@unilim.fr (T. Amine), jsw7@st-andrews.ac.uk (J.O.S. Wilson).
} 


\title{
Liquidity Regulation and Bank Risk
}

This version: September 23, 2021

Preliminary draft. Not edited. Please do not quote without permission of the authors.

\begin{abstract}
In this paper, we investigate the impact of liquidity requirements on bank risk. We take advantage of the implementation of the Liquidity Balance Rule (LBR) in the Netherlands in 2003 and analyze its impact on bank default risk. The LBR was imposed on Dutch banks only and did not apply to other banks operating elsewhere within the Eurozone. Using this differential regulatory treatment to overcome identification concerns, we find that following the introduction of the LBR, the risk of Dutch banks declined relatively to counterparts not affected by the rule. Concomitantly, despite the lower cost of funding driven by the LBR, the profitability of Dutch banks decreased in comparison with other banks in Europe, as a result of a decrease in income accruing from interest-bearing activities. Our findings also indicate that relatively to unaffected banks, Dutch banks might not have actively tried to offset their loss in interest income by increasing interest rates of loans. However, better financing conditions allowed Dutch banks to increase the shares of deposits and capital on the liability side of their balance sheets.
\end{abstract}

JEL Classification: G21, G28

Keywords Banking, liquidity regulation, Netherlands, propensity score matching, quasi-natural experiment, risk, stability. 


\section{Introduction}

Until the liquidity shortages that occurred upon the onset of the global financial crisis, little attention had been paid to the importance of bank liquidity and its implications for bank risk. Since then, coordinated international agreements under the auspices of Basel III have required banks to enhance liquidity via adherence to: a Liquidity Coverage Ratio (LCR), which requires that banks hold enough high-quality liquid assets to survive a stress scenario spanning a one month duration; and a Net Stable Funding Ratio (NSFR) which requires banks to hold a minimum amount of stable deposit funding to withstand a closure of wholesale funding markets (Basel Committee on Banking Supervision, 2009, 2013). Given the paucity of relevant empirical research and the importance of liquidity for individual banks and the wider banking industry, in this study we investigate the impact of liquidity regulation on bank risk.

Ex ante, it is unclear whether the introduction of liquidity regulations aimed at reducing the maturity mismatch between banks' illiquid assets and liquid liabilities leads to an increase or decrease in risk given that banks have a myriad of ways to manage liquidity (DeYoung and Jang, 2016). ${ }^{2}$ On the one hand, liquidity regulation that requires banks to hold higher levels of liquid assets as a buffer against liquidity shocks leads to a subsequent decline in risk and the probability of bank runs (Diamond and Kashyap, 2016). Moreover, liquidity regulation similar in format to that introduced under Basel III Liquidity Coverage Ratio allows banks to comply with regulatory requirements via increases in capital (Hartlage, 2012). Thus, bank resilience to negative balance sheet shocks is also improved (Hoerova et al., 2018). Banks can also swap funding from sources (such as wholesale funding) that are less favored by capital regulation with sources (such as retail deposits) attracting more favorable regulatory treatment. In doing so, banks can reduce the cost of capital, increase profitability, and build up capital buffers to withstand external shocks to balance sheets. On the other hand, attracting more retail deposits may increase bank risk in the presence of safety-net guarantees, such as deposit insurance schemes (Lambert et al. 2017). Liquidity regulation

\footnotetext{
2 Bonner et al. (2015) use data from 30 different countries and find that the correlations of bank liquidity buffers to deposit liabilities, market concentration, and bank size are substantially weaker in countries with bank liquidity regulations. The authors contend that liquidity regulations act as substitutes for active liquidity management and limit excessive risk-taking by banks.
} 
may force banks to increase investments in more liquid, but lower yielding assets, which leads to a subsequent decline in profitability. Faced with declining profitability, banks may invest remaining funds in riskier investments in order to boost returns (Hoerova et al., 2018; Bosshardt and Kakhbod, 2020). Consequently, the introduction of liquidity regulation can lead to an increase in bank risk.

Assessing the impact of liquidity regulations on bank risk is not straightforward given that such rules are often introduced and phased in alongside other safety and soundness regulation. In the present study, we overcome these challenges via a research design that utilizes an unanticipated policy intervention as a quasi-natural experiment to investigate the impact of liquidity regulation on bank risk. We use the Netherlands at a setting, where in 2003 a Liquidity Balance Rule (LBR) was introduced. Under the terms of the LBR, banks are required to hold high-quality liquid assets that exceed or are equal to net cash outflows over a 30-day stress period. The introduction of the LBR in the Netherlands did not occur following a period of financial system instability and was not anticipated in advance by banks and other industry stakeholders. The LBR only applied to Dutch banks and did not apply to other banks operating elsewhere in the Eurozone. As a consequence, we use this differential regulatory treatment to overcome identification concerns and investigate the impact of liquidity regulation on the risk of Dutch banks.

We use accounting-based measures of bank risk comprising the standard deviation of the return on assets and a bank default risk measure along with its asset and leverage risk sub-components. Market-based indicators are also constructed for a sub-sample of listed banks using the standard deviation of bank daily stock returns over a calendar year and a market-based version of the bank default risk measure. The sample period straddles the introduction of the LBR. Our data set comprises unconsolidated balance sheet, off-balance sheet and income statement data for commercial banks covering the period 2000 to 2006 for 12 Eurozone member countries (Austria, Belgium, Finland, France, Germany, Greece, Ireland, Italy, Luxembourg, Netherlands, Portugal, and Spain).

To assess the impact of the LBR on bank risk, we use a difference-in-differences approach where we estimate the difference in the riskiness of affected banks between the pre-LBR and post-LBR period with the same difference in the riskiness of a control group of banks. In order to avoid possible selection bias, and following prior literature based on European data (Schepens, 2016, Ananou et al 2021), we use propensity score matching to 
form a control group of similar banks drawn from Eurozone countries where the LBR was not introduced. Our baseline model includes bank level characteristics, as well as country time-varying controls that prior literature considers as important determinants of bank risk.

The main results of our empirical analysis indicate that following the introduction of the LBR both the risk-taking (either measured by asset risk or stock price volatility) and default risk of Dutch banks decreased in comparison with counterparts not subject to the LBR. Moreover, the decline in bank default risk occurred primarily through a reduction of leverage risk (as bank became better capitalized). These findings are consistent across both accounting and market-based indicators of bank risk. Although the systematic risk of Dutch banks remained unchanged following the introduction of the LBR, their specific risk decreased relative to other banks not subject to the provisions of the LBR.

In a series of additional tests, we investigate the impact of the introduction of the LBR on bank profitability, cost of funding and funding structure. Our findings suggest that, following the introduction of the LBR, Dutch banks changed their funding structure by increasing capital and deposits. We also document that profitability declined despite reduced funding costs. We find that this is because Dutch banks experienced a decrease in the interests received on their assets following the introduction of the LBR. Specifically, the decrease in the cost of funding that occurred following the introduction of the rule was not enough to offset the negative impact of lower interest on earning assets on profitability. Nevertheless, the impact of LBR on profitability is short lived and disappears four years following the liquidity regulation change.

Our baseline results are not sensitive to variations in the matching procedure including the number of countries used to match treated and control banks, the control variables included in the estimation of the propensity score, or the number of matched banks included in the sample. The internal validity of our findings is satisfied by insignificant placebo tests that confirm the causal interpretation of our results.

Our study contributes to the recent literature on the impact of liquidity regulation on bank behavior. This literature suggests that liquidity regulation has a significant impact on domestic and cross border bank lending (De Nicolo et al., 2014; Covas and Driscoll, 2014; Reinhardt et al, 2020). Moreover, some studies show that the imposition of liquidity regulation requires banks to adjust their balance sheet mix by increasing the share of high- 
quality liquid assets and by reducing reliance on short-term wholesale funding (Duijm and Wierts, 2016; Banerjee and Mio, 2018). In the case of the Netherlands itself, prior evidence suggests that the introduction of the LBR led affected banks to change the volume and composition of lending. Specifically, the enactment of the LBR led to an increase in the overall volume of lending and a re-orientation toward corporate lending as well as to the accumulation of more stable deposit and equity funding (Ananou et al, 2021). A decline in inter-bank lending is also evident (Bonner and Eijffinger, 2016). Complementing this literature, our difference-in-differences approach used in the empirical analysis allows us to identify the causal impact of differences in liquidity requirements across banks on risk and the pricing of assets and liabilities.

Our findings also contribute to research that explores the determinants of bank risk. Prior evidence suggests that macroeconomic conditions (Athanasoglou et al. 2008; Albertazzi and Gambacorta 2009), competition (Beck et al., 2013; Liu et al, 2013; Goetz, 2018), ownership (lannotta et al., 2007; Barry et al, 2011); size (De Haan, and Poghosyand, 2012); funding structure (Demirguc-Kunt and Huizinga, 2010; Vazquez and Federico, 2015; Khan et al., 2017), capital (Berger, 1995; Giordana and Schumacher, 2017), diversification (Demsetz and Strahan, 1997; DeYoung and Roland, 2001; Lepetit et al, 2008), corporate governance (Berger et al., 2016; Anginer et al, 2018); loan growth (Foos et al, 2002) and business models (Altunbas et al., 2011; Kohler, 2015) pursued by banks impact risk.

We also contribute to a literature examining the importance of various types of liquidity for bank risk. Wagner (2007) finds that increases in bank liquidity reduces the likelihood of bank runs and thus leads banks to increase risk-taking. Kohler (2015) finds that retailoriented banks are riskier as their share of non-deposit to total funding increases. Using a sample of US commercial banks, Hong et al., (2014) find that the NSFR and the LCR did not predict bank failures. Rather systemic liquidity risk was a major contributor to the US bank failures observed immediately following the global financial crisis. For a sample of European banks, Chiaramonte and Casu (2017) find that banks with higher structural liquidity (values of the Basel III NFSR) are less likely to default. The authors find that the LCR is not related to bank default risk. We augment this literature by documenting that a change in asset liquidity requirements induces a long-lasting reduction in risk of affected banks. Specifically, the reduction in default risk is driven by a reduction in leverage risk (i.e., improved capitalization in order to cover asset risk). 
The remainder of the paper is organized as follows. Section 2 describes the empirical methodology and presents the data and summary statistics of the sample. In Section 3, we present the results of our empirical analysis. Section 4 provides additional evidence, which corroborates that liquidity requirements reduce the level of bank risk. Sensitivity checks are described in Section 5. Section 6 concludes.

\section{Research design}

\subsection{Data and sample}

Our sample comprises commercial banks based in the 12 European countries (Austria, Belgium, Finland, France, Germany, Greece, Ireland, Italy, Luxembourg, the Netherlands, Portugal, Spain) forming the Eurozone by 2003 over the 2000-2006 period. We retrieve accounting data from the BankScope database compiled by Bureau van Dijk. All of the banks in our sample (European banks) report annual financial statements with fiscal year ending December 31. For each bank, we use unconsolidated data if available; otherwise, we use consolidated statements. For the period and countries covered by this study, we identify commercial banks that have at least three consecutive years of observations for net income, total equity, and total assets. ${ }^{3}$ To minimize the effect of outliers, we remove banks by eliminating extreme observations (5\% lowest and highest values) for each financial variable of interest. In order to reduce the possible impact of mergers and acquisitions that took place during the sample period, we also discard all bank-year observations where growth in total assets exceeds $25 \%$. Our final sample comprises 400 commercial banks including 16 Dutch banks.

In our analysis, we also construct a subsample dataset of listed banks. We retrieve daily market data from the Bloomberg database. The subsample is restricted to banks with continuously daily traded stocks between the 1st of January 2000 and 31st December 2006. We obtain a final subsample of 117 listed banks. Columns (1) and (3) of Table 2 presents information regarding the geographic distribution of the initial sample of banks.

\subsection{Measures of Bank Risk}

\footnotetext{
${ }^{3}$ This criterion enables us to compute rolling-window standard deviations to construct our risk indicators.
} 
To measure bank risk, we use the standard deviation of the return on assets (SDROA) computed on a rolling window of three years. We also consider the Z-Score as a proxy for bank default risk. We compute a variable named ZSCORE as proposed by Boyd and Graham (1986):

$$
\mathrm{ZSCORE}=\frac{\text { MROA }+ \text { EQUITY }}{\text { SDROA }}
$$

where MROA is the three-year rolling window average return on assets, defined as the ratio of net income to total assets, and EQUITY is the ratio of total equity to total assets. SDROA denotes the standard deviation of the return on assets computed on a rolling window of three years

We follow Goyeau and Tarazi (1992) and Lepetit et al. (2008) and decompose the ZSCORE into its constituent components, defined as Z1SCORE and Z2SCORE. ${ }^{4}$ Z1SCORE measures asset risk, while Z2SCORE is a measure of leverage risk. These two measures allow us to capture whether a change in ZSCORE is driven by a change in asset and/or in leverage risk. For robustness, we consider SDROA using a four-year rolling window and a five-year rolling window. ZSCORE is then computed with these alternative definitions of SDROA.

Given that accounting-based variables may not accurately capture sudden changes in bank risk, we complement these measures with market-based indicators for a sub-sample of listed banks. Risk is measured using the standard deviation of bank daily stock returns within a calendar year (SDRETURN). ${ }^{5}$ To assess default risk, we calculate a market-based ZScore (MZSCORE) defined as:

$$
\text { MZSCORE }=(1+\text { RETURN }) / \text { SDRETURN }
$$

where RETURN is the average of bank daily stock returns within a calendar year. We also consider systematic risk as measured by BETA and the bank specific risk (IVOL). BETA and IVOL are obtained by estimating the market model, for each year:

$$
R_{i, t}=a_{i}+\beta_{i} R_{m, t}+\varepsilon_{i, t}
$$

where $R_{i, t}$ is bank i's daily stock return, and $R_{m, t}$ is the daily return of a market portfolio $m$.

\footnotetext{
${ }^{4}$ ZSCORE $=$ Z1SCORE + Z2SCORE $=$ MROA/SDROA + EQUITY $/$ SDROA

${ }^{5}$ Bank daily stock return is computed as the logarithm of the ratio of two adjacent daily stock prices (i.e., In(Price /Price $_{\mathrm{t}-1}$ )
} 
We use the Euro Overnight Index Average rate as proxy for the market portfolio. BETA takes the values of the estimated coefficient $\beta_{i}$ and IVOL is obtained as the standard deviation of the residuals from the regression. For robustness, we also compute SDRETURN, MZSCORE, BETA and IVOL using bank daily stock returns over the last three months of each year from 2000 to 2006.

\subsection{Methodology}

The research design employed in the current study allows us to identify the causal impact of liquidity regulation on bank risk. To that end, we rely on the introduction of the LBR in the Netherlands in 2003, which provides an exogenous variation in the liquid assets held by Dutch banks. ${ }^{6}$ The regulation was announced in January 2003, and Dutch banks had until July 2003 to comply with its terms (de Haan and den End 2013).

The LBR stipulates that Dutch banks should hold high-quality liquid assets greater than or equal to net cash outflows over a 30-day stress period. The LBR is defined as a ratio, where the numerator comprises the weighted sum of the stock of liquid assets and cash inflow scheduled within the next 30 days. The denominator comprises the weighted sum of the stock of liquid liabilities and cash outflow scheduled within the next 30 days. In order to comply with the regulation, the ratio of a given bank should be equal to or exceed one. The weights represent the relative liquidity of the items included in the ratio and are determined by the regulator (DNB, 2011).

Our analysis is based on propensity score matching combined with difference-indifferences estimation, which compares the change in risk of Dutch banks between the pre-LBR and post LBR period, with the change in risk of a similar group of European banks for which the LBR did not apply. The baseline model is as follows:

$$
Y_{i, t}=\beta_{1}\left(\text { Affected }_{i} \times \text { PostEvent }_{t}\right)+\delta X_{i, t-1}+\alpha_{i}+\lambda_{t}+\varepsilon_{i, t}
$$

where $i$ indexes bank and $t$ indexes time. $Y_{i, t}$ is a measure of bank risk. We proxy bank risk

\footnotetext{
${ }^{6}$ The LBR is conceptually similar to the Basel III LCR, which requires banks to hold a minimum level of liquid assets to meet a stress scenario of outflows. The main difference is in the weighting scheme and the range of items included in the stock of liquid assets which is more extensive for the LBR compared to the LCR.
} 
using SDROA and ZSCORE as well as its constituent components Z1SCORE and Z2SCORE for the full sample, whereas for the sub-sample of listed banks only, we use their marketbased equivalents SDRETURN, BETA, IVOL and MZSCORE. Affected $i$ is a dummy variable equal to one for banks affected by the LBR (Dutch banks) and zero otherwise. PostEvent $t$ is a dummy variable for the treatment period, equal to one for the years 2003 onwards, and zero otherwise. $X_{i, t-1}$ represents a vector of bank-level control variables that vary across banks and over time, which prior literature considers as important determinants of bank risk. These variables are defined in Section 2.4 below. To control for changes in the domestic economic environment, we also include the real GDP growth rate and inflation. To avoid simultaneity, we lag each of our control variables by one period. The model also includes bank specific fixed effects, $\alpha_{i}$, to control for unobserved bank heterogeneity, and time dummies $\lambda_{t}$ to capture time effects common to all banks.

Key to our identification strategy is the assumption that in the absence of treatment the coefficient of interest $\beta_{1}$ is zero. This is also known as the parallel trend assumption. To ensure that the coefficient $\beta_{1}$ captures the effect of the LBR rather than a sample selection effect, we use a propensity score matching procedure to construct a control group of European banks such that treated, and control banks share similar trends in terms of risk (Roberts and Whited, 2013; Schepens, 2016). Therefore, we compute propensity scores based upon trends in the ZSCORE over the pre-treatment period for the full sample (and the MZSCORE for the subsample of listed banks) and other balance sheet characteristics as well as national economic conditions in the pre-treatment period (prior to the introduction of the LBR). ${ }^{7}$ Specifically, the propensity scores are computed using the growth rate in ZSCORE (respectively MZSCORE); ratio of total deposits to total assets; ratio of total equity to total assets; return on assets, real GDP growth and inflation, and the levels of total assets and the lagged value of ZSCORE (MZSCORE). Hence, we select banks of similar size, portfolio composition, capital structure, income and facing similar economic conditions in the pre-treatment period. The propensity scores are used to match each Dutch bank with its three nearest neighbors for the full sample and five nearest neighbors for the

\footnotetext{
${ }^{7}$ We consider trends in ZSCORE (MZSCORE) for the full sample (for the subsample of publicly listed banks) because all the risk measures are highly correlated, as shown in the correlation matrix in table 3. We are therefore confident that the other measures of risk employed in our analysis follow a similar trend. For robustness (section 5), we use trends in SDROA and SDRETURN to run the matching and our findings remain identical with these measures.
} 
subsample of listed banks. ${ }^{8}$ The matching is executed with replacement. This means that each non-Dutch bank can serve as a control for multiple Dutch banks. This improves the accuracy of the matching procedure (Smith and Todd, 2005).

The matching procedure leads to a control group that comprises 42 banks drawn from other Eurozone countries for the broad sample of banks. For the subsample of listed banks, we end up with a control group that comprises 13 banks drawn from other Eurozone countries. ${ }^{9}$ The impact of the matching procedure is illustrated in Table 4 . The table provides summary statistics for the main variables of interest for the three years prior to the introduction of the LBR and the three years after the introduction. The table also reports mean differences test between Dutch and the wider sample of eurozone banks from which the control group of banks are selected.

The summary statistics show that the parallel trend assumption is violated when using the full sample of non-Dutch banks as control group. Banks operating in Netherlands differ in various characteristics, compared to other European banks. For example, Dutch banks are on average larger and have significantly a higher risk of default during the pretreatment period. The success of the matching is illustrated in the last three columns of the table. The difference in means between Dutch banks and the matched group of banks is not statistically significant for all bank characteristics. Furthermore, the growth rates of bank risk measures are similar for banks in both groups.

[Insert Table 4 here]

Figure 1 depicts the evolution of two of the bank risk measures considered in our analysis (namely ZSCORE and MZSCORE) over the period 2000 to 2006. Both variables follow similar paths in the pre-treatment period lending support to the notion that the parallel trends assumption is not violated in our setting. However, from 2003, we observe diverging trends for the affected and control banks. This is suggestive evidence that the introduction of the LBR has had an impact on Dutch banks' risk.

\section{[Insert Figure 1 here]}

\footnotetext{
${ }^{8}$ We choose 5 neighbors for the listed banks to gain more observations necessary to compute statistical tests.

${ }^{9}$ Columns (2) and (4) of table 2 present the distribution of banks in the control group by country.
} 


\subsection{Control variables}

All our regressions include a set of control variables, which are expected to affect bank risk. This comprises the natural logarithm of bank total assets (SIZE) and the ratio of equity to total assets (EQUITY) to respectively account for bank size and capitalization. Larger banks have greater ability to diversify their activities and should be less risky (Demsetz and Strahan, 1997). But because of the presence of too-big-to-fail policies, they might also have higher incentives to take more risk (Galloway et al., 1997). The effect of bank capitalization on default risk is expected to be negative. However, its effect on risktaking is not clear. Banks with higher capital ratios (on a market-value basis) are safer and take less risk, due to the moderating effect of charter values (Keeley, 1990). However, higher capital ratios due to more stringent capital regulation can encourage banks to take on more risk to maintain the expected return to shareholders (Koehn and Santomero, 1980; Kim and Santomero, 1988).

Bank funding is captured by the ratio of deposits to total assets (DEPOSITS). Banks with higher deposits-to-assets ratio are expected to be riskier. Demirguc-Kunt and Detragiache (2002), Demirguc-Kunt and Kane (2002) and Barth et al. (2004) indicate that when deposits are insured, depositors lack the incentives to monitor banks activities, thus leading bank to excessive risk-taking. We also introduce the ratio of total loans to total assets (LOANS). Its impact on risk is expected to be negative because loans are usually more stable than non-traditional intermediation activities (lannotta et al., 2007). Lending is part of banks' traditional activity. Through the screening of their clients, they would be able to offset the impact of an increase in lending on their default risk. However, the literature consistently finds that excessive rates of loan growth led to greater risk-taking (Foos et al., 2010).

To control for differences in banks' business models, we include the ratio of net noninterest income to net operating income (NNI). Greater reliance on non-interest income activities is generally found to be associated with higher risk (Stiroh, 2004; Lepetit et al., 2008, Demirgüc-Kunt and Huizinga 2010, Altunbas et al. 2011). Liikanen (2012) indicates that income from non-interest activities is more volatile, which can negatively affect the stability of a bank.

To account for operational efficiency, we consider the cost to income ratio 
(COSTINCOME), which should have a positive effect on risk. Under the "bad management" hypothesis by DeYoung (1997), banks operating with low levels of efficiency have higher costs largely due to inadequate credit monitoring and inefficient control of operating expenses (which is reflected in lower cost efficiency almost immediately). Declines in cost (and revenue) efficiency will temporally precede increases in banks' risk due to credit, operational, market and reputational problems. Shehzad et al., (2010); Barry et al., (2011), Saramiento and Galan (2017) found evidence which support this argument.

\section{Results}

In this section, we discuss the results of our regression analysis, which assesses the possible impact of the introduction of the LBR on bank risk. Table 5 presents the results of estimating equation (1). We follow the recent literature analyzing bank-risk measures such as Z-Score or the standard deviation of returns and apply a log transformation to all the outcome variables. ${ }^{10}$ The estimated models include bank-specific control variables to capture any potential shocks in one of the time-varying determinants of bank risk. We also include year fixed effects to capture effects common to all banks, and bank fixed effects to account for any unobservable time invariant bank characteristics.

\section{[Insert Table 5 here]}

In all regressions, using either an accounting or a market-based risk measures of risk as outcome variable, the $\beta_{1}$ coefficient on the interaction term of interest is negative and significant for SDROA, SRETURN and positive and significant for ZSCORE, Z2SCORE and MZSCORE. This implies that following the introduction of the LBR, Dutch banks' risk-taking became lower leading to a lower probability of default, as captured by the Z-score measures, relative to counterparts not subject to the LBR. For instance, the standard deviation of return on assets of the average Dutch bank was reduced by $45 \%$ relatively to an average bank not subject to the LBR. For the average Dutch bank, the ZSCORE increased by $51 \%$ relative to the average non-Dutch bank not subject to the LBR. The results also

\footnotetext{
${ }^{10}$ Lepetit and Strobel (2015) indicate that log-transformed Z-scores may be more appropriate in applied work due to the skewness of Z-scores in levels. They add that the log of the Z-score can additionally be shown to be negatively proportional to the log odds of insolvency, giving it a sound probabilistic foundation. For comparability, we harmonize all the variables by applying a log transformation
} 
show that these changes occur mainly through a reduction in leverage risk. Specifically, we observe a positive impact of the introduction of the LBR on Z2SCORE; the impact on Z1SCORE is not significant. The results also reveal that on average, for Dutch banks, specific risk decreased relatively to other banks not subject to the provision of the LBR. This is in line with the view that the introduction of liquidity requirements would lead to a decline in risk and the probability of bank runs (Diamond and Kashyap, 2016, Hoereva et al. 2018).

Turning to our control variables, we focus our discussion on the specification with ZSCORE as an outcome variable (column 1) in Table 5. Regarding the bank-level variables SIZE enters the regression with a positive coefficient that is statistically significant at the $1 \%$ level. This suggests that a one percent increase in SIZE is associated with a 0.7 percent increase in ZSCORE. This is line with the view that larger banks have greater ability to diversify their activities and hold more diversified loan portfolios which is effective in reducing risk (Demsetz and Strahan, 1997). We also find that better capitalized banks (EQUITY) are associated with lower default risk, as expected. Interestingly, when the outcome variable is SDROA (column 4) better capitalized banks are found to take higher asset risk which is consistent with the view that higher capitalization allows banks to fund riskier projects without jeopardizing their solvency. DEPOSITS and COSTINCOME enter the regression with positive, but insignificant coefficients, while LOAN and NNI enter the regression with a negative, but insignificant coefficient. These variables are non-significant in any of the other regressions with different outcome variables. Finally, GROWTH enters the regression with a negative, but marginally significant coefficient, while the coefficient on INFLATION is negative and statistically insignificant. Growth only shows a significant coefficient in column 4 where the outcome variable is SDROA. In periods of booms, our results hence show that banks tend to increase the riskiness of their asset portfolio which is consistent with the findings of previous studies (Bohachova, 2008; Altunbas et al. 2010; Madaloni and Peydro, 2010; Haq and Heaney, 2012).

On the whole, our results show that the introduction of the LBR has reduced both the risk-taking and default risk of banks subject to the rule. However, an important issue is whether such an impact is transitory or long-lived. Indeed, to comply with the rule banks need to make quick adjustments by increasing the share of liquid assets on the liability side of their balance sheet or by reducing the share of non-stable funding in their liabilities. However, once they have adjusted to the new requirements, banks could also react by 
increasing the riskiness of their non-liquid assets to maintain their profitability. To investigate this issue, we follow Jorda (2005) and Favara and Imbs (2015) to determine the dynamic effect of liquidity regulation on bank risk and profitability. Specifically, we employ local projections, which consist of running a sequence of predictive regressions of a variable of interest (e.g., risk or profitability) on a regulatory shock (e.g., LBR) for different horizons to obtain impulse response functions. In the context of our analysis, the impulse response functions correspond to a sequence of estimates $\beta_{1}^{j}$ obtained from the estimations of:

$$
Y_{i, t+j}=\beta_{1}^{j}\left(\text { Affected }_{i} \times \text { PostEvent }_{t}\right)+\delta X_{i, t-1}+\alpha_{i}+\lambda_{t}+\varepsilon_{i, t}
$$

where each $\beta_{1}^{j}$ captures the effect of the introduction of the LBR at horizon $j$, with $j=1, \ldots, 5$. Also, other regulatory changes (such as the publication of the preliminary draft of Basel II requirements) that may have occurred at the regional or international level during the period when the LBR was announced and implemented would affect banks in the Eurozone the same way. Thus, our analysis is unlikely to be influenced by such changes and the IRF will capture the long run effect of the introduction of the LBR. Figure 2 plots the impulse response functions. For both the ZSCORE and SDRETURN, the impulse response function shows a significant impact until the fifth year, although the magnitude of the impact diminishes over the years. This suggest that the introduction of the LBR has an immediate but not short-lived effect on bank risk.

Overall, we find that following the introduction of the LBR, Dutch banks became less risky relative to counterparts not subject to the rule. The observed impact is not simply statistically significant, but also economically significant. On average, ZSCORE increased by approximately $51 \%$, while SDROA decreased by around $45 \%$, compared to counterparts not subject to the rule. As such, it appears that the introduction of the LBR leads banks to take lower risk and become less vulnerable to default.

\section{Impact on bank profitability, income, cost of funding and funding structure}

In this section, we examine the impact of the introduction of the LBR on bank profitability and on their cost of funding and funding structure. Hoereva et al (2018) indicate that banks face a tradeoff between risk and profitability when facing liquidity constraints. Thus, a 
decrease in bank risk should be accompanied by a decline in profitability, given that the return on liquid assets is likely to be lower than the return on illiquid assets. They argue that funding cost matters for bank profitability and risk, particularly in an environment where banks are subject to an LCR-like standard. They emphasize that when the return on liquid assets is lower than funding cost, banks may have incentives to invest in riskier assets to offset the negative impact on their profitability of holding larger portions of liquid assets. Banks can also adjust to the loss in income driven by the constraint of holding larger shares of liquid assets by adjusting their lending rates. This implies that banks can actively engage in a pricing policy to limit the negative impact on their income, but such a strategy will be dependent on the degree of competition on the loan market. Banks could also collude in ways that the increase in lending rates is beneficial to all the players in the banking industry but detrimental to borrowers. Giordana et al (2017) also argue that any impact of an increase in liquid assets on profitability is crucially dependent on the structure of bank liabilities. Our results indicate that following the implementation of the LBR, Dutch banks became less vulnerable to default and took less risk. A priori, we also expect to observe a negative or insignificant impact of the introduction of the LBR on profit, and a significant effect on bank funding structure and costs of Dutch banks. To investigate these issues, we consider the reduced form of a DiD model as follows:

$$
Y_{i, t}=\beta_{1}\left(\text { Affected }_{i} \times \text { PostEvent }_{t}\right)+\alpha_{i}+\lambda_{t}+\varepsilon_{i, t}
$$

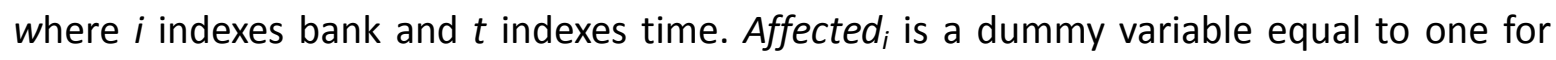
banks affected by the LBR (Dutch banks) and zero otherwise. PostEvent $t_{t}$ is a dummy variable for the treatment period. It takes the value of 1 for the years 2003 onwards, and zero otherwise. $B_{1}$ is the coefficient of interest, which represents the impact of the LBR on one of our outcome variables: profitability, cost of funding and, funding structure variables. The model also includes bank specific fixed effects, $\alpha_{i}$, to control for unobserved bank heterogeneity, and time dummies $\lambda_{t}$ to capture time effects common to all banks.

\subsection{Bank profitability, interest margins and non-interest income}

To assess the effect of the introduction of the LBR on bank profitability and interest 
margins and other income components, we consider the return on assets (ROA) and various components of bank income comprising: the ratio of total interest income to total assets (IINC); and the ratio of non-interest income to total assets (NII). We further investigate the structure of bank revenue by analyzing the impact of the introduction of the LBR on components of non-interest income comprising the ratio of net gain/loss from trading activities to total non-interest income (TRADEGAIN); ratio of net fees and commissions to total non-interest income (COM); and the ratio of other non-interest income to total non-interest income (EXTRA). The results of the estimations are presented in Table 6. As expected, the LBR has a negative and significant impact on bank profitability. This is driven mainly by a reduction in income generated by interest bearing activities as opposed to non-interest income. However, the effect is not permanent. The last row of figure 2 shows the impulse response function of ROA to the introduction of the LBR. It indicates that four years after the introduction of the LBR, the effect of LBR becomes insignificant. Nevertheless, closer inspection of non-interest income reveals a heterogenous impact of the LBR. Specifically, following the introduction of the LBR income generated by trading activities declines; other non-interest income increases; and income from fees and commissions remains unchanged. This suggests a shift from trading to other non-interest generating activities of Dutch banks.

\section{[Insert Table 6 here]}

Overall, the results suggest that the introduction of the LBR lead to a reduction in Dutch banks' income possibly due to the requirement of holding larger shares of less profitable liquid assets. Alternatively, following Hoereva et al (2018), another potential explanation to this result could be that Dutch banks face higher funding costs because they hold riskier assets in reaction to the introduction of the LBR. If depositors and other types of debt holders effectively discipline banks, then they would indeed actually require a higher rate of return on their holdings. Banks could also adjust to the new regulatory environment by increasing the interest rate charged on illiquid assets which could have a detrimental effect if it leads to credit rationing by hoarding out the safest borrowers (Stiglitz and Weiss, 1981). We investigate this issue in the next section. 


\subsection{Cost of funding and loan pricing}

To investigate the impact of the LBR on bank funding cost and loan pricing, we consider the difference (NIM) between the implicit interest rate charged, INT (measured by the ratio of total interest income to total earning assets) and paid, COST (measured by the ratio of total interest expenses to total liabilities). The results are presented in Table 7. We find that the coefficient of the interaction term $\left(\right.$ Affected $_{i} x$ PostEvent $_{t}$ ) enters the regression with a negative and statistically significant coefficient at the $5 \%$ level. The magnitude of the coefficient suggests that Dutch banks suffer from a reduction in their interest margin (NIM) by 40 basis points on average, following the introduction of the liquidity regulation. Further analysis of the components of NIM suggests that both the implicit interest rate charged by banks on their assets (INT) and that paid on their liabilities (COST) decreased following the introduction of the LBR. However, INT declines by more than COST, leading to the observed narrowing of NIM for the Dutch banks.

Overall, it appears that Dutch banks did not actively try to offset their loss in income as they did not charge higher interest on their assets, relatively to non-affected banks. They also benefit from better financing conditions which should allow them to increase the shares of deposits and capital on the liability side of their balance sheets, which are helpful for compliance (Hartlage 2012) and to offset insolvency risk arising from a decline in profitability. We investigate this issue in the next section.

[Insert Table 7 here]

\subsection{Funding structure}

To assess the impact on banks' funding structure, we consider EQUITY and DEPOSITS as outcome variables. The results of the estimation are presented in table 8.

[Insert Table 8 here]

The results indicate that Dutch banks have experienced an inflow of deposits, but also an increase in equity. A potential explanation is that Dutch banks may have increased equity in order to offset the increased insolvency risk arising from a decline in profitability. Eisenbach et al. (2014) and Konig (2015) argue that when bank profits decline as a result of an increase in liquid assets, insolvency risk also increases. Therefore, by increasing capital, banks can offset any negative impact on their stability. 


\section{Robustness and sensitivity analysis}

In this section, we examine the robustness of our main results. To ensure that our results are not affected using overlapping periods (rolling-windows), we compute our accountingbased risk variables based on 4-year and 5-year rolling windows. For the subsample of listed banks, we consider the last three months of the year to compute the market-based risk indicators. We re-estimate equation (1) using these measures. The results of the estimations are presented in row (1), (2) and (3) of Table 9. The results remain qualitatively similar to those reported in Table 5.

Next, we test whether variations in our matching procedure affects our results. First, we run the matching using the trends in SDROA and SDRETURN, instead of ZSCORE and MZSCORE. In the baseline analysis, we assume that the evolution of all the outcome variables should be similar to ZSCORE and MZSCORE, given the strong correlation between all these indicators. The results of the estimation of Equation (1) using this alternative matching are presented in row (4) of Table 9. The results hold, and the magnitude of the coefficient are in line with our baseline results. We also vary the number of matched banks from three nearest neighbors to the nearest neighbor only and then to the five nearest neighbors and obtain similar results (see rows 5 and 6). Finally, we restrict the number of countries from which banks in the control group are selected. We use Belgium and Luxembourg for the control group, given that along with the Netherlands these countries are part of the historical BENELUX economic union. An analysis based on these three countries is likely to address any omitted variable bias. Given the specific nature of the banking system in Luxembourg (which specializes on wealth management), we conduct a further robustness check using only Belgian banks as our control group. The results remain unchanged qualitatively (see rows 7 and 8).

Finally, we test for the parallel trend assumption by performing a placebo test. In order to investigate the effect of a placebo treatment, we assume that the LBR was introduced in 2001, rather than in 2003. We then re-run the matching using the growth rate of ZSCORE and MZSCORE. The matching procedure is the same as that used in the baseline analysis. The estimations are presented in row (9) of Table 9 and suggest that the parallel trend assumption is not violated, and thus the identification strategy is valid. 
[Insert Table 9 here]

\section{Conclusion}

In this study we conduct an extensive investigation into how liquidity regulation impacts bank risk. To identify the impact of bank liquidity regulation on bank risk we use the Liquidity Balance Rule, which was introduced in the Netherlands in 2003, and required Dutch banks to hold high-quality liquid assets greater than or equal to net cash outflows over a 30-day stress period.

We conduct an extensive difference in differences empirical analysis at the bank level, where we compare the riskiness of Dutch banks between the pre-LBR and post-LBR period with the same difference in the riskiness of a control group of European banks not subject to the provision of the LBR. Our analysis produces two major findings. First, we show that following the introduction of the LBR Dutch banks became less risky, but their profitability was negatively impacted. Second, we find that the introduction of the LBR led Dutch banks to change their funding structure by increasing capital and deposits. The decrease in the cost of funding following the introduction of the LBR possibly explains such a change.

Our findings have implications for public policy and government agencies monitoring the impacts of the recently phased in Liquidity Coverage Ratio on the banking industry. Given prior evidence (including the global financial crisis) shows that a lack of bank liquidity can have implications for the safety and soundness of banks, the results presented in the present study suggest that the introduction of liquidity regulation reduces bank risk and the likelihood of default. Our findings do not lend support to the views that the introduction of liquidity requirements could be counterproductive by encouraging banks to take on more risk to avoid the negative impact of such rules on bank profitability. However, because the introduction of the LBR has led to a decline in bank profitability, bank stability could be a concern. Bank managers and supervisors should be cautious about banks' solvency levels which can more likely be maintained with equity issuance rather than with reserves generated by non-distributed income. 


\section{References}

Albertazzi, U., Gambacorta, L., 2009. Bank Profitability and the Business Cycle. Journal of Financial Stability 5 (4), 393-409.

Altunbas, Y., Manganelli, S., Marques-lbanez, D., 2011. Bank risk during the financial crisis: Do business models matter? European Central Bank Working Paper Series 1394.

Ananou, F., Chronopoulos, D., Tarazi, A., Wilson, J.O.S., 2021. Liquidity Regulation and Lending, Journal of Corporate Finance 69(1).

Anginer, D., Demirguc-Kunt, A., Huizinga, H., Ma, K., 2018. Corporate governance of banks and financial stability. Journal of Financial Economics, 130(2):327-346.

Athanasoglou, P., Brissimis, S.N., Delis, M., 2008. Bank-specific, industry-specific and macroeconomic determinants of bank profitability, Journal of International Financial Markets, Institutions and Money, 18:121-136.

Banerjee, R. N., Mio, H., 2018. The Impact of liquidity regulation on banks. Journal of Financial Intermediation 35:30-44.

Barry, T.A., Lepetit, L., Tarazi, A., 2011. Ownership structure and risk in publicly held and privately owned banks. Journal of Banking \& Finance 35 (5):1327-1340.

Basel Committee on Banking Supervision, 2009. International framework for liquidity risk measurement, standards, and monitoring. Basel: Bank of International Settlements.

Basel Committee on Banking Supervision, 2013. Basel III: The Liquidity Coverage Ratio and liquidity risk monitoring tools. Basel: Bank of International Settlements.

Beck, T., De Jonghe O., Schepens G., 2013. Bank Competition and Stability: Cross-country heterogeneity. Journal of Financial Intermediation 22:218-244.

Berger, A. N., 1995. The Relationship between Capital and Earnings in Banking. Journal of Money, Credit, and Banking 27 (2):432-456

Berger, A.N., Imbierowicz, B., Rauch, C., 2016. The Roles of Corporate Governance in Bank Failures during the Recent Financial Crisis, Journal of Money, Credit and Banking.

Bohachova, O. 2008. The Impact of Macroeconomic Factors on Risks in the Banking Sector: A CrossCountry Empirical Assessment. IAW Discussion Papers No 44, Institut für Angewandte Wirtschaftsforschung (IAW).

Bonner, C., Eijffinger, S. C. W., 2016. The impact of liquidity regulation on bank intermediation. Review of Finance 20(5):1945-79.

Bonner, C., van Lelyveld, I., Zymek, R., 2015. Banks' liquidity buffers and the role of liquidity regulation. Journal of Financial Services Research 48(3): 215-234.

Bosshardt, J., Kakhbod, A., 2020. The Effect of Liquidity Regulation on U.S. Bank Risk-Taking: Evidence from Non-Performing Loans and CDS Spreads. MIT Dept. of Economics Working Papers Series. SSRN: http://dx.doi.org/10.2139/ssrn.3550912

Boyd, J.H., Graham, S.L., 1986. Risk, regulation, and bank holding company expansion into nonbanking. Federal Reserve Bank of Minneapolis Quarterly Review 10 (2): 2-17. 
Chiaramonte, L., 2018. Bank liquidity and the global financial crisis. Basingstoke: Palgrave MacMillan.

Chiaramonte, L., Casu, B., 2017. Capital and liquidity ratios and financial distress: Evidence from the European banking industry. British Accounting Review 49(2):138-61.

Covas, F., Driscoll, J. C., 2014. Bank liquidity and capital regulation in general equilibrium. FEDS Working Paper Number 2014-85.

DeYoung, R., Roland, K.P., 2001. Product mix and earnings volatility at commercial banks: Evidence from a degree of total leverage model. Journal of Financial Intermediation 10: 54-84

Duijm, P., Wierts, P., 2016. The Effects of liquidity liabilities regulation on bank assets and liabilities. International Journal of Central Banking 12(2):385-411.

DNB, 2011. Regulating Liquidity under Wft. Amsterdam: DNB.

Diamond, D.W., Kashyap, A., 2016. Liquidity requirements, liquidity choice, and financial stability, In: Taylor, J. B., Uhlig, H. (eds.) Handbook of Macroeconomics. Amsterdam: Elsevier.

De Haan, J., Poghosyand. T., 2012. Bank Size, Market Concentration, and Bank Earnings Volatility in the US. Journal of International Financial Institutions, Markets and Money 22 (1):35-54.

Demirguc-Kunt, A., Huizinga, H., 2010. Bank activity and funding strategies: The impact on risk and returns. Journal of Financial Economics 98(3):626-650.

Demsetz, R.S., Strahan, P.E., 1997. Diversification, size, and risk at bank holding companies. Journal of Money, Credit and Banking 29 (3): 300-313.

De Nicolò, G., Gamba, A., Lucchetta, M., 2014. Microprudential regulation in a dynamic model of banking. Review of Financial Studies 27(7):2097-2138.

DeYoung, R., Roland, K., 2001. Product Mix and Earnings Volatility at Commercial Banks: Evidence from a Degree of Total Leverage Model. Journal of Financial Intermediation 10: 54-84.

DeYoung, R., \& Jang, K. Y., 2016. Do banks actively manage their liquidity? Journal of Banking and Finance, 66, 143-161.

Eisenbach, T. M., Keister, T., McAndrews, J. J., Yorulmazer, T., 2014. Stability of funding models: an analytical framework. FRBNY Economic Policy Review.

Favara, G., Imbs, J., 2015. Credit supply and the price of housing. American Economic Review 105(3):958-92.

Foos, D., Norden, L., Weber, M., 2010. Loan growth and riskiness of banks. Journal of Banking \& Finance 34(12):2929-2940.

Giordana, G. A., Schumacher, I., 2017. An empirical study on the impact of Basel III standards on banks' default risk: The case of Luxembourg. Journal of Risk and Financial Management 10(2): 829

Goetz, M. R. (2018). Competition and bank stability. Journal of Financial Intermediation, 35, 57-69.

Goyeau, D., Tarazi, A., 1992. Évaluation du risque de défaillance bancaire en Europe. Revue d'Économie Politique 102:249-280.

Hartlage, A.W., 2012. The Basel III liquidity coverage ratio and financial stability. Michigan Law Review 111(3). 
Haq, M., Heaney, R., 2012. Factors determining European bank risk. Journal of International Financial Markets, Institutions and Money 22(4): 696-718.

Hoerova, M., Mendicino, C., Nikolov, K., Schepens, G., Van den Heuvel, S., 2018. Benefits and costs of liquidity regulation. ECB Working Paper Series Number 2169.

Hong, H., Huang, J.-Z., Wu, D., 2014. The information content of Basel III liquidity risk measures. Journal of Financial Stability 15:91-111.

lannotta, G., Nocera, G., Sironi, A., 2007. Ownership structure, risk, and performance in the European banking industry. Journal of Banking \& Finance, 31:2127-2149.

Jorda O., (2005), Estimation and inference of impulse response by local projection. American Economic Review 95 :161-182.

Khan, M. S., Scheule, H., Wu, E., 2017. Funding liquidity and bank risk taking. Journal of Banking \& Finance 82:203-216.

Köhler, M., 2015. Which banks are more risky? The impact of business models on bank stability. Journal of Financial Stability, 16, 195-212.

Konig, P. J., 2015. Liquidity requirements: A double-edged sword. International Journal of Central Banking 42:129-168.

Lambert, C., Noth, F., Schuwer, U., 2017. How do insured deposits affect bank risk? Evidence from the 2008 Emergency Economic Stabilization Act. Journal of Financial Intermediation 29:81-102.

Lepetit, L., Nys, E., Rous, P., Tarazi, A., 2008. Bank income structure and risk: An empirical analysis of European banks. Journal of Banking \& Finance 32, 1452-1467.

Liu, H., Molyneux, P., Wilson, J.O.S., 2013. Competition and Stability in European Banking: A Regional Analysis Manchester School, 2013, 81, 176-201.

Maddaloni, A, Peydro, J.L., 2010. Bank Risk-taking, Securitization, Supervision, and Low Interest Rates: Evidence from the Euro-area and the U.S. Lending Standards. ECB Working Paper 1248.

Roberts, M. R., Whited, T. M., 2013. Endogeneity in empirical corporate finance. In Constantinides, G., Milton, H. and Stulz. R (eds.) Handbook of the Economics of Finance. Vol. 2 Amsterdam: Elsevier.

Schepens, G., 2016. Taxes and bank capital structure. Journal of Financial Economics 120(3), 585600.

Smith, J. A., Todd, P. E., 2005. Does matching overcome LaLonde's critique of non-experimental estimators? Journal of Econometrics 125(1-2):305-53.

Wagner, W., 2007. The Liquidity of bank assets and banking stability. Journal of Banking \& Finance, 31(1): 121-139. 
Figure 1. Evolution of ZSCORE and MZSCORE for Dutch banks and control banks Panel 1. ZSCORE

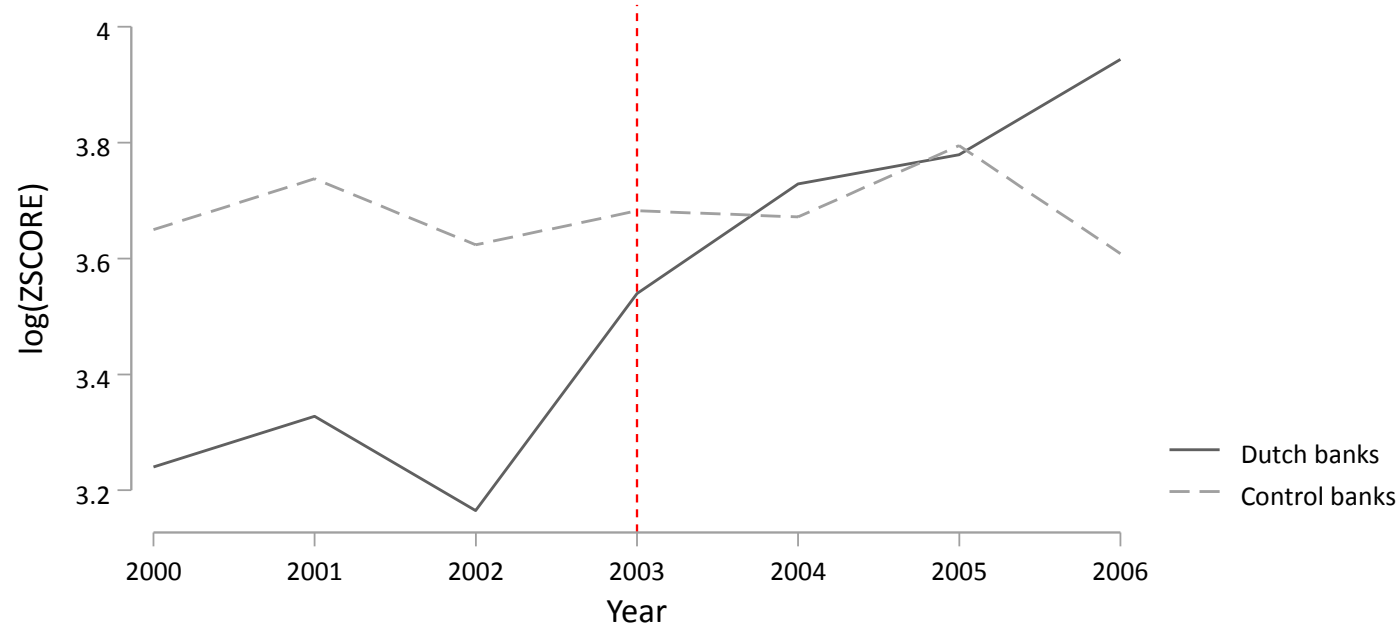

Panel 2. MZSCORE

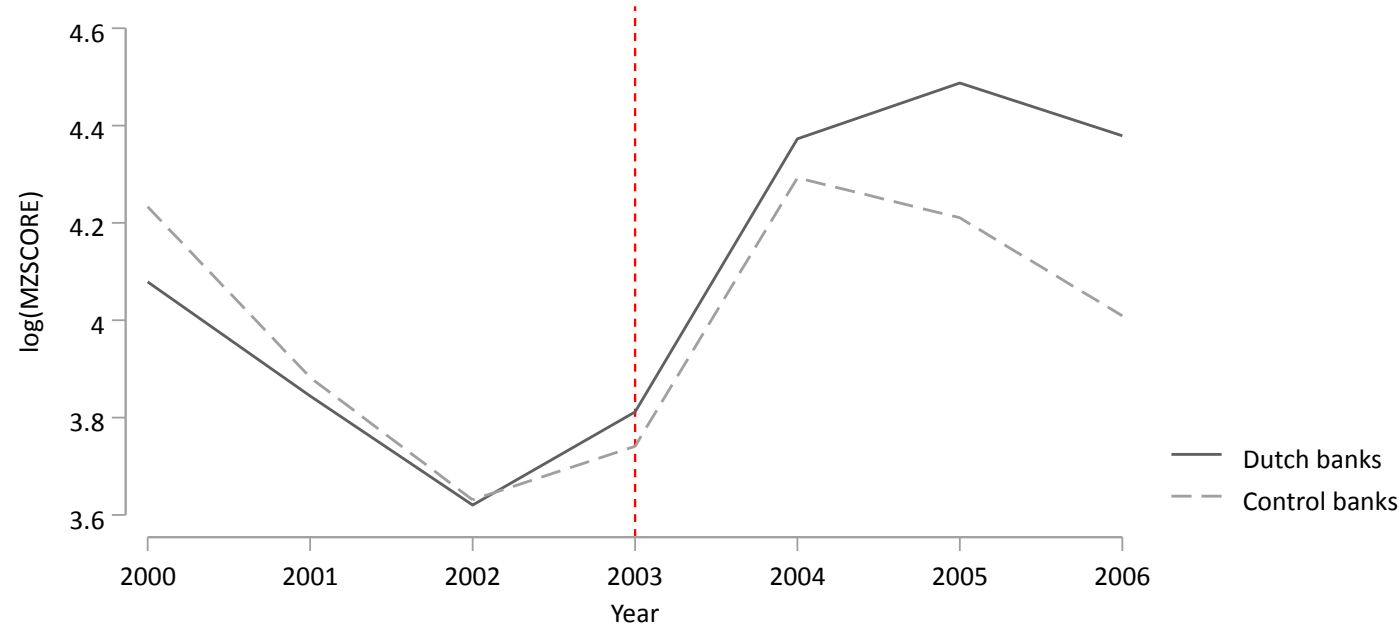


Figure 2. Bank risk and profitability response to the introduction of the LBR
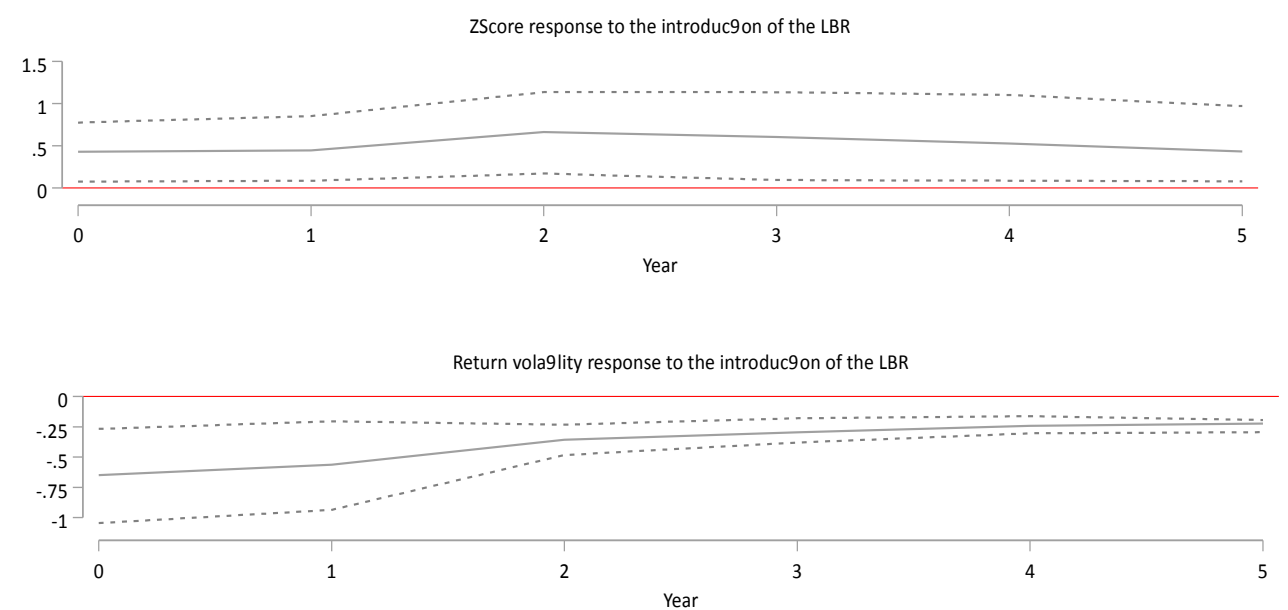

Return on assets (ROA) response to the introduc9on of the LBR

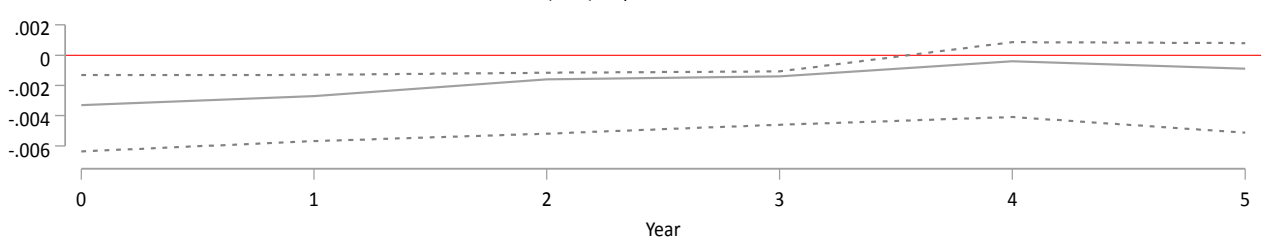

Notes: This figure plot the impulse responses of bank risk (ZSCORE and SDRETURN) and profitability (ROA) to the introduction of the LBR. The IRFs are computed following the method proposed by Jorda (2005). Doted lines are the 95 percent confidence bands. 
Table 1. Variable definitions

\begin{tabular}{|c|c|c|c|}
\hline Variable & Description & Source & $\begin{array}{l}\text { Expected } \\
\text { sign }\end{array}$ \\
\hline \multicolumn{4}{|c|}{ Dependent variables } \\
\hline BETA & $\begin{array}{l}\text { Systematic risk computed by regressing bank daily stock return on a } \\
\text { benchmark market excess return within a calendar year. BETA is the } \\
\text { coefficient associated with the market excess return }\end{array}$ & Author computed & \\
\hline IINC & Ratio of interest income to total assets (\%) & Author computed & \\
\hline INT & Ratio of total interest income on to total earning assets (\%) & Author computed & \\
\hline IVOL & $\begin{array}{l}\text { Bank specific risk computed as the annualized standard deviation of the } \\
\text { residuals of the regression of bank daily returns on a benchmark market } \\
\text { excess return. }\end{array}$ & Author computed & \\
\hline COST & Ratio of total interest expenses on to total liabilities (\%) & Author computed & \\
\hline MZSCORE & $\begin{array}{l}\text { Market based Z-Score defined as (100+RETURN)/SDRETURN where RETURN } \\
\text { and SDRETURN are expressed in percentages. }\end{array}$ & Author computed & \\
\hline NII & Ratio of non-interest income to total assets (\%) & Author computed & \\
\hline NIM & Net interest margin defined as the difference between INT and COST & Author computed & \\
\hline ROA & Return on assets defined as the ratio of net income to total assets (\%) & Bankscope & \\
\hline SDRETURN & $\begin{array}{l}\text { Market based bank risk defined as the geometric standard deviation of daily } \\
\text { stock returns within a calendar year (\%) }\end{array}$ & Bloomberg & \\
\hline SDROA & Three-year rolling window standard deviation of ROA (\%) & Author computed & \\
\hline ZSCORE & $\begin{array}{l}\text { Bank default risk. ZSCORE = }(M R O A+E Q U I T Y) / S D R O A \text {, where EQUITY is the } \\
\text { ratio of total equity to total assets; and MROA is the three-year rolling } \\
\text { window average of ROA }\end{array}$ & Author computed & \\
\hline ZSCORE1 & First component of ZSCORE. ZSCORE1 = MROA/SDROA & Author computed & \\
\hline ZSCORE2 & Second component of ZSCORE. ZSCORE2 = EQUITY/SDROA & Author computed & \\
\hline \multicolumn{4}{|c|}{ Control variables } \\
\hline COSTINCOME & Cost to income ratio (\%) & Bankscope & - \\
\hline DEPOSITS & Ratio of customer deposits to total assets (\%) & Bankscope & + \\
\hline EQUITY & Ratio of total equity to total assets (\%) & Bankscope & $+/-$ \\
\hline GROWTH & Year-to-year growth rate of real GDP & Eurostat & \\
\hline INFLATION & Year-to-year growth rate of harmonized price index & Eurostat & \\
\hline LOANS & Ratio of net loans to total assets (\%) & Bankscope & $+/-$ \\
\hline $\mathrm{NNI}$ & Ratio of net noninterest income to net operating income (\%) & Bankscope & - \\
\hline SIZE & Natural logarithm of total assets & Bankscope & $+/-$ \\
\hline
\end{tabular}

Notes: This table presents definitions for all variables used throughout the paper. The first column shows the name of the variable as used throughout the paper, the second describes the corresponding definition and the third column gives the source 
Table 2. Distribution of commercial banks in the sample by Country

\begin{tabular}{lcccc}
\hline \multirow{2}{*}{ Country } & \multicolumn{2}{c}{$\begin{array}{c}\text { Broad } \\
\text { sample of banks }\end{array}$} & \multicolumn{2}{c}{$\begin{array}{c}\text { Subsample } \\
\text { of listed banks }\end{array}$} \\
\cline { 2 - 5 } & $\begin{array}{c}\text { Full } \\
\text { sample }\end{array}$ & $\begin{array}{c}\text { Matched } \\
\text { sample }\end{array}$ & $\begin{array}{c}\text { Full } \\
\text { sample }\end{array}$ & $\begin{array}{c}\text { Matched } \\
\text { sample }\end{array}$ \\
\cline { 2 - 5 } & $(1)$ & $(2)$ & $(3)$ & $(4)$ \\
\hline Austria & 38 & 5 & 8 & 0 \\
Belgium & 20 & 3 & 4 & 1 \\
Finland & 3 & 0 & 4 & 1 \\
France & 90 & 9 & 26 & 3 \\
Germany & 86 & 9 & 23 & 4 \\
Greece & 11 & 0 & 1 & 0 \\
Ireland & 5 & 1 & 0 & 0 \\
Italy & 20 & 1 & 10 & 1 \\
Luxembourg & 60 & 8 & 14 & 0 \\
Netherlands & 16 & 16 & 4 & 4 \\
Portugal & 11 & 3 & 7 & 1 \\
Spain & 40 & 3 & 16 & 2 \\
\hline
\end{tabular}

Notes: This table indicates for each country, the number of commercial banks included in the full sample 
Table 3. Correlation matrix

\begin{tabular}{|c|c|c|c|c|c|c|c|c|c|c|c|}
\hline \multicolumn{12}{|c|}{ Panel 1. Broad sample of banks } \\
\hline & 1 & 2 & 3 & 4 & 5 & 6 & 7 & 8 & 9 & 10 & 11 \\
\hline 1. SDROA & 1.00 & & & & & & & & & & \\
\hline 2. ZSCORE & -0.37 & 1.00 & & & & & & & & & \\
\hline 3. ZSCORE1 & -0.40 & 0.73 & 1.00 & & & & & & & & \\
\hline 4. ZSCORE2 & -0.36 & 0.97 & 0.70 & 1.00 & & & & & & & \\
\hline 5. NII & 0.12 & -0.17 & -0.06 & -0.17 & 1.00 & & & & & & \\
\hline 6. COSTINCOME & 0.14 & -0.11 & -0.28 & -0.10 & 0.17 & 1.00 & & & & & \\
\hline 7. DEPOSITS & -0.03 & -0.02 & 0.07 & -0.02 & 0.08 & 0.20 & 1.00 & & & & \\
\hline 8. EQUITY & 0.31 & 0.18 & -0.05 & 0.19 & -0.03 & -0.14 & -0.16 & 1.00 & & & \\
\hline 9. SIZE & -0.23 & -0.06 & 0.12 & -0.07 & -0.04 & -0.11 & -0.26 & -0.42 & 1.00 & & \\
\hline 10. LOANS & -0.13 & 0.07 & 0.14 & 0.06 & -0.35 & 0.06 & 0.18 & -0.15 & -0.02 & 1.00 & \\
\hline 11. LLR & 0.13 & -0.11 & -0.02 & -0.11 & -0.04 & 0.18 & 0.17 & -0.07 & -0.15 & 0.28 & 1.00 \\
\hline \multicolumn{12}{|c|}{ Panel 2. Subsample of listed banks } \\
\hline 1.SDRETURN & 1.00 & & & & & & & & & & \\
\hline 2. MZSCORE & -0.35 & 1.00 & & & & & & & & & \\
\hline 3. BETA & 0.44 & -0.18 & 1.00 & & & & & & & & \\
\hline 4. IVOL & 0.99 & -0.34 & 0.06 & 1.00 & & & & & & & \\
\hline 5. NII & -0.01 & 0.02 & 0.08 & -0.03 & 1.00 & & & & & & \\
\hline 6. COSTINCOME & 0.22 & -0.10 & 0.18 & 0.21 & 0.11 & 1.00 & & & & & \\
\hline 7. DEPOSITS & 0.13 & -0.03 & -0.14 & 0.16 & 0.09 & 0.11 & 1.00 & & & & \\
\hline 8. EQUITY & -0.11 & 0.09 & -0.14 & -0.08 & -0.12 & -0.19 & -0.23 & 1.00 & & & \\
\hline 9. SIZE & -0.01 & -0.17 & 0.64 & -0.12 & -0.01 & 0.21 & -0.27 & -0.07 & 1.00 & & \\
\hline 10. LOANS & -0.04 & 0.10 & -0.02 & -0.03 & -0.06 & 0.00 & 0.20 & 0.17 & -0.20 & 1.00 & \\
\hline 11. LLR & -0.02 & 0.05 & -0.22 & 0.03 & -0.09 & -0.12 & -0.04 & 0.15 & -0.34 & 0.43 & 1.00 \\
\hline
\end{tabular}

Notes: This table reports the correlation matrix for the outcome variables and control variables used in our analysis. 
Table 4. Summary statistics

\begin{tabular}{|c|c|c|c|c|c|c|c|c|}
\hline & \multicolumn{2}{|c|}{ Dutch banks } & \multicolumn{3}{|c|}{ Full control group } & \multicolumn{3}{|c|}{ Matched control group } \\
\hline & Mean & Std. Dev. & Mean & Std. Dev. & Diff & Mean & Std. Dev. & Diff \\
\hline \multicolumn{9}{|c|}{ Panel A: Pre LBR period } \\
\hline SDRETURN & 1.970 & 1.105 & 1.841 & 1.546 & 0.129 & 2.182 & 0.861 & -0.211 \\
\hline MZSCORE & 50.219 & 4.621 & 91.679 & 6.554 & $-41.460 * * *$ & 54.091 & 4.195 & -3.872 \\
\hline MZSCOREGW & -6.496 & 8.536 & 22.042 & 4.892 & $-28.539 * *$ & -6.155 & 6.184 & 0.058 \\
\hline BETA & 0.562 & 0.596 & 0.196 & 0.335 & $0.365^{* *}$ & 0.443 & 0.458 & 0.119 \\
\hline IVOL & 1.600 & 0.738 & 1.757 & 1.516 & -0.157 & 1.983 & 1.917 & -0.383 \\
\hline ROA & 1.111 & 1.592 & 0.600 & 1.217 & $0.512^{* *}$ & 0.842 & 1.501 & 0.271 \\
\hline SDROA & 0.610 & 0.727 & 0.377 & 0.574 & $0.233^{* *}$ & 0.453 & 0.674 & 0.156 \\
\hline ZSCORE & 49.796 & 9.349 & 76.265 & 13.543 & $-26.469 * * *$ & 66.887 & 6.458 & $-19.443 *$ \\
\hline ZSCOREGW & 29.057 & 12.036 & 53.466 & 7.72 & $-24.409 * * *$ & 26.883 & 12.831 & 2.174 \\
\hline ZSCORE1 & 3.804 & 4.293 & 5.054 & 5.795 & $-1.249 *$ & 4.985 & 5.761 & -1.182 \\
\hline ZSCORE2 & 46.105 & 8.854 & 71.126 & 2.541 & $-25.022 * * *$ & 64.180 & 6.791 & $-18.075^{*}$ \\
\hline $\mathrm{NNI}$ & 27.782 & 16.799 & 37.649 & 23.420 & $-9.866 * * *$ & 24.744 & 24.109 & 2.600 \\
\hline COSTINCOME & 53.401 & 18.444 & 62.532 & 22.166 & $-9.131 * * *$ & 51.726 & 24.152 & 1.680 \\
\hline DEPOSITS & 48.647 & 28.726 & 51.370 & 24.879 & -2.727 & 45.685 & 20.208 & 2.962 \\
\hline EQUITY & 11.415 & 11.435 & 9.733 & 12.955 & 1.681 & 10.280 & 9.644 & 1.135 \\
\hline SIZE & 8.115 & 1.776 & 7.403 & 1.991 & $0.711^{* * *}$ & 7.869 & 2.242 & 0.245 \\
\hline LOANS & 46.579 & 24.552 & 46.602 & 27.689 & -0.592 & 48.729 & 27.041 & -2.718 \\
\hline LLR & 0.631 & 0.489 & 1.999 & 2.302 & $-1.363^{* * *}$ & 0.863 & 2.061 & -0.232 \\
\hline GROWTH & 1.350 & 0.656 & 2.009 & 1.894 & $-0.659 * * *$ & 2.009 & 1.894 & $-0.659 * * *$ \\
\hline INFLATION & 0.329 & 0.172 & 0.599 & 0.617 & $-0.269 * * *$ & 0.599 & 0.617 & $-0.269 * * *$ \\
\hline \multicolumn{9}{|c|}{ Panel B : Post LBR period } \\
\hline SDRETURN & 0.923 & 0.588 & 1.209 & 1.830 & -0.286 & 1.079 & 2.825 & -0.157 \\
\hline MZSCORE & 83.851 & 5.282 & 129.318 & 12.775 & $-45.467 * * *$ & 74.275 & 6.883 & $10.611^{* * *}$ \\
\hline MZSCOREGW & 31.508 & 20.718 & 12.761 & 3.776 & 18.474 & 27.774 & 9.498 & $3.734^{* * *}$ \\
\hline BETA & 0.534 & 0.566 & 0.231 & 0.389 & $0.303^{*}$ & 0.542 & 0.417 & 0.007 \\
\hline IVOL & 0.754 & 0.155 & 1.161 & 0.106 & $-0.407 * *$ & 0.971 & 0.438 & -0.216 \\
\hline ROA & 0.857 & 1.625 & 0.742 & 1.211 & 0.146 & 1.034 & 0.701 & $-0.178^{*}$ \\
\hline SDROA & 0.407 & 0.549 & 0.362 & 0.581 & 0.0004 & 0.517 & 0.768 & 0.111 \\
\hline ZSCORE & 67.871 & 8.932 & 79.054 & 2.680 & -11.182 & 71.488 & 7.076 & -3.292 \\
\hline ZSCOREGW & 33.021 & 10.977 & 60.891 & 9.96 & $-27.872^{*}$ & 25.198 & 9.349 & $8.171^{* * *}$ \\
\hline ZSCORE1 & 4.486 & 3.414 & 5.342 & 5.661 & -0.856 & 5.180 & 5.615 & -0.694 \\
\hline ZSCORE2 & 63.295 & 8.513 & 73.405 & 2.547 & -10.110 & 66.233 & 6.696 & -2.784 \\
\hline NNI & 26.904 & 18.875 & 39.828 & 23.494 & $-12.925 * * *$ & 39.207 & $25 / 841$ & $-8.894^{*}$ \\
\hline COSTINCOME & 52.348 & 16.445 & 59.879 & 21.944 & $-7.530 * * *$ & 57.743 & 24.205 & $-5.394^{* *}$ \\
\hline DEPOSITS & 52.468 & 28.410 & 52.448 & 25.142 & 0.020 & 45.584 & 20.917 & $6.883^{* *}$ \\
\hline EQUITY & 11.940 & 10.432 & 9.662 & 12.874 & 1.431 & 9.682 & 12.363 & 1.358 \\
\hline SIZE & 8.425 & 1.849 & 7.653 & 2.020 & $0.772^{* * *}$ & 7.571 & 2.391 & $0.854^{* *}$ \\
\hline LOANS & 47.993 & 26.154 & 48.026 & 28.738 & -0.908 & 50.421 & 28.271 & -3.203 \\
\hline LLR & 1.481 & 2.259 & 2.099 & 2.160 & -0.617 & 1.261 & 1.286 & 0.221 \\
\hline
\end{tabular}




\begin{tabular}{lllllllll} 
GROWTH & 1.521 & 0.555 & 1.996 & 1.894 & $-0.474 * * *$ & 1.996 & 1.894 & $-0.474^{* * *}$ \\
INFLATION & 0.566 & 0.852 & 0.598 & 0.606 & -0.032 & 0.598 & 0.606 & -0.032 \\
\hline
\end{tabular}

Notes: This table reports summary statistics of the outcome variables and the control variables for Dutch banks and nonDutch banks in the pre-treatment (Panel A) and post treatment (Panel B) periods. MZSCOREGW and ZSCOREGW respectively describe the growth rates of MZSCORE and ZSCORE. *,**,*** indicate significance at the $10 \%, 5 \%$, and $1 \%$ levels, respectively for the difference in means test (t-test) between Dutch and Eurozone banks.

Table 5. Impact of LBR on bank risk

\begin{tabular}{|c|c|c|c|c|c|c|c|c|}
\hline \multirow{3}{*}{ Variables } & \multicolumn{4}{|c|}{ Panel 1 : Broad sample of banks } & \multicolumn{4}{|c|}{ Panel 2 : sub sample of listed banks } \\
\hline & ZSCORE & Z1SCORE & Z2SCORE & SDROA & SDRETURN & BETA & IVOL & MZSCORE \\
\hline & (1) & (2) & (3) & (4) & (5) & (6) & (7) & (8) \\
\hline \multirow[t]{2}{*}{ Affected x PostEvent } & $0.434 * * *$ & 0.380 & $0.430 * * *$ & $-0.579 * *$ & $-0.329 * *$ & -0.881 & $-0.301 * *$ & $0.329 * *$ \\
\hline & $(0.190)$ & $(0.641)$ & (0.189) & $(0.196)$ & $(0.115)$ & (0.934) & $(0.107)$ & $(0.133)$ \\
\hline \multirow[t]{2}{*}{ DEPOSITS } & 0.001 & $0.031^{* *}$ & -0.001 & 0.007 & -0.002 & -0.012 & -0.023 & $0.021 * *$ \\
\hline & $(0.005)$ & $(0.013)$ & $(0.005)$ & $(0.007)$ & $(0.008)$ & $(0.021)$ & $(0.076)$ & $(0.008)$ \\
\hline \multirow[t]{2}{*}{ EQUITY } & $0.041^{* *}$ & $-0.025 * *$ & & $0.017^{* *}$ & $-0.019 * *$ & -0.004 & $-0.024 * *$ & $0.019 * *$ \\
\hline & $(0.009)$ & $(0.011)$ & & $(0.009)$ & (0.009) & $(0.031)$ & $(0.008)$ & $(0.009)$ \\
\hline \multirow[t]{2}{*}{ SIZE } & $0.661 * * *$ & $0.316^{* * *}$ & $0.651 * * *$ & $-0.116 * * *$ & $-0.151 * *$ & 0.021 & $-0.149 * * *$ & $0.151^{* *}$ \\
\hline & $(0.105)$ & $(0.087)$ & $(0.106)$ & $(0.104)$ & $(0.056)$ & $(0.024)$ & $(0.062)$ & $(0.067)$ \\
\hline \multirow[t]{2}{*}{ LOANS } & -0.005 & $-0.015^{* *}$ & -0.005 & 0.005 & 0.082 & $0.003^{* *}$ & 0.083 & -0.083 \\
\hline & $(0.006)$ & (0.099) & $(0.006)$ & $(0.006)$ & $(0.311)$ & $(0.001)$ & $(0.283)$ & $(0.312)$ \\
\hline \multirow[t]{2}{*}{ NNI } & -0.004 & -0.001 & 0.004 & -0.0001 & 0.001 & -0.000 & 0.000 & -0.001 \\
\hline & $(0.005)$ & $(0.006)$ & $(0.005)$ & $(0.004)$ & $(0.001)$ & $(0.001)$ & $(0.001)$ & $(0.001)$ \\
\hline \multirow[t]{2}{*}{ COSTINCOME } & 0.005 & $-0.035 * * *$ & 0.004 & 0.003 & 0.004 & $0.001^{* *}$ & 0.003 & -0.004 \\
\hline & $(0.005)$ & $(0.008)$ & $(0.004)$ & $(0.004)$ & $(0.006)$ & $(0.000)$ & $(0.006)$ & $(0.007)$ \\
\hline \multirow[t]{2}{*}{ LLR } & $-0.013^{* *}$ & $-0.029 * *$ & $-0.013 * *$ & -0.020 & $-0.151 * *$ & $-0.328^{*}$ & $-0.150^{* *}$ & $0.151^{* *}$ \\
\hline & $(0.007)$ & $(0.094)$ & $(0.007)$ & $(0.228)$ & $(0.067)$ & $(0.201)$ & $(0.052)$ & $(0.057)$ \\
\hline \multirow[t]{2}{*}{ GROWTH } & $-0.043^{*}$ & $0.059 *$ & -0.045 & $0.022^{* *}$ & $-0.054 * *$ & -0.008 & $-0.052^{*}$ & $0.053^{* *}$ \\
\hline & $(0.027)$ & $(0.036)$ & $(0.053)$ & $(0.004)$ & (0.019) & $(0.071)$ & $(0.043)$ & $(0.020)$ \\
\hline \multirow[t]{2}{*}{ INFLATION } & -0.055 & $0.012^{* * *}$ & -0.052 & -0.108 & 0.062 & $-0.033^{* *}$ & $0.078^{* *}$ & -0.062 \\
\hline & $(0.074)$ & $(0.000)$ & $(0.074)$ & $(0.101)$ & $(0.072)$ & (0.011) & $(0.034)$ & (0.039) \\
\hline Year fixed effects & Yes & Yes & Yes & Yes & Yes & Yes & Yes & Yes \\
\hline Bank fixed effects & Yes & Yes & Yes & Yes & Yes & Yes & Yes & Yes \\
\hline Observations & 294 & 294 & 294 & 294 & 86 & 86 & 86 & 86 \\
\hline R-squared & 0.974 & 0.826 & 0.973 & 0.904 & 0.978 & 0.903 & 0.982 & 0.978 \\
\hline
\end{tabular}

Notes: The table analyses the impact of the introduction of the Liquidity Balance Rule in the Netherlands on bank risk in a difference-in-differences setup. The sample consists of banks from the Netherlands and the matched non-Dutch banks over the 2000-2006 period. In Panel 1, all the regressions are performed on a sample of 58 commercial banks. In Panel 2, all regressions are performed on a sample of 18 listed banks. ZSCORE is a measure of bank default risk, Z1SCORE is a measure of bank asset risk; Z2SCORE is a measure of bank leverage risk. SDRETURN is the standard deviation of daily stock returns within a calendar year. BETA is a measure of systematic risk and IVOL is a measure of idiosyncratic risk. MZSCORE is a market-based Z-Score defined as $(100+$ RETURN)/SDRETURN. All the dependent variables were log transformed. AFFECTED is a dummy is equal to 1 when the bank is a Dutch bank and 0 otherwise. POSTEVENT is a dummy equal to 1 for the years 2003 to 2006 and 0 otherwise. The model is estimated using OLS. The control variables comprise: SIZE defined as the natural logarithm of total assets, EQUITY defined as the ratio of total equity to total assets, DEPOSITS defined as the ratio of total customer deposits to total assets. LOANS is defined as of net loans to total assets. COSTINCOME is the ratio of operating expense over total operating income. LLR is the ratio of loan loss 
reserves to total assets, GROWTH is the real GDP growth and INFLATION is the inflation rate. The effect of LBR is captured by the coefficient on the interaction term Affected $\times$ Post Event. $*, * *, * * *$ indicate significance at the $10 \%, 5 \%$, and $1 \%$ levels, respectively.

Table 6. Impact of LBR on bank profitability and income

\begin{tabular}{lcccccc}
\hline Variables & ROA & IINC & NII & TRADEGAIN & COM & \multicolumn{2}{c}{ EXTRA } \\
& $(1)$ & $(2)$ & $(3)$ & $(4)$ & $(5)$ & $(6)$ \\
\hline Affected x PostEvent & $-0.004^{* *}$ & $-0.019^{* *}$ & -0.006 & $-0.123^{* *}$ & 0.823 & $0.076^{* *}$ \\
& $(0.002)$ & $(0.010)$ & $(0.009)$ & $(0.007)$ & $(1.824)$ & $(0.002)$ \\
Year fixed effects & Yes & Yes & Yes & Yes & Yes & Yes \\
Bank fixed effects & Yes & Yes & Yes & Yes & Yes & Yes \\
Observations & 406 & 258 & 258 & 95 & 95 & 95 \\
R-squared & 0.769 & 0.908 & 0.744 & 0.515 & 0.942 & 0.896
\end{tabular}

Notes: The table analyses the impact of the introduction of the Liquidity Balance Rule in the Netherlands on bank profit, equity and deposits in a difference-in-differences setup. The sample consists of banks from the Netherlands and the matched non-Dutch banks over the 2000-2006 period. ROA is a measure of bank's profitability, IINC is the ratio of interest income to total assets, NII is the ratio of non-interest income to total assets, TRADEGAIN is the ratio net gain/loss from trading activities to total non-interest income, COM is the ratio of net fees and commissions to total non-interest income and EXTRA is the ratio of other non-interest income to total non-interest income. AFFECTED is a dummy is equal to 1 when the bank is a Dutch bank and 0 otherwise. POSTEVENT is a dummy equal to 1 for the years 2003 to 2006 and 0 otherwise. The model is estimated using OLS. The effect of LBR is captured by the coefficient on the interaction term Affected $x$ PostEvent. $*, * * * *$ indicate significance at the $10 \%, 5 \%$, and $1 \%$ levels, respectively.

\section{Table 7. Impact of LBR on bank interest margin, interest charged and funding cost}

\begin{tabular}{lccc}
\hline Variables & NIM & INT & COST \\
& $(1)$ & $(2)$ & $(3)$ \\
\hline Affected x PostEvent & $-0.004^{* *}$ & $-0.021^{* *}$ & $-0.016^{* *}$ \\
& $(0.004)$ & $(0.009)$ & $(0.000)$ \\
Year fixed effects & Yes & Yes & Yes \\
Bank fixed effects & Yes & Yes & Yes \\
Observations & 261 & 261 & 261 \\
R-squared & 0.848 & 0.913 & 0.819
\end{tabular}

Notes: The table analyses the impact of the introduction of the Liquidity Balance Rule in the Netherlands on bank profit, equity and deposits in a difference-in-differences setup. The sample consists of banks from the Netherlands and the matched non-Dutch banks over the 2000-2006 period. COST is the ratio of total interest expenses to total liabilities, INT is the ratio of total interest income to total earning assets, and NIM is the difference between INT and COST (NIM $=$ INT-COST). AFFECTED is a dummy is equal to 1 when the bank is a Dutch bank and 0 otherwise. POSTEVENT is a dummy equal to 1 for the years 2003 to 2006 and 0 otherwise. The model is estimated using OLS. The effect of LBR is captured by the coefficient on the interaction term Affected $\times$ PostEvent. ${ }^{*}, * *, * * *$ indicate significance at the $10 \%, 5 \%$, and $1 \%$ levels, respectively. 
Table 8. Impact of LBR on bank funding structure

\begin{tabular}{lcc}
\hline Variables & DEPOSITS & $\begin{array}{c}\text { EQUITY } \\
(5)\end{array}$ \\
\hline Affected x PostEvent & $0.009^{* *}$ & $0.019^{* *}$ \\
& $(0.000)$ & $(0.000)$ \\
Year fixed effects & Yes & Yes \\
Bank fixed effects & Yes & Yes \\
Observations & 364 & 406 \\
R-squared & 0.963 & 0.927 \\
\hline
\end{tabular}

Notes: The table analyses the impact of the introduction of the Liquidity Balance Rule in the Netherlands on bank profit, equity and deposits in a difference-in-differences setup. The sample consists of banks from the Netherlands and the matched non-Dutch banks over the 2000-2006 period. DEPOSITS is the ratio of total customer deposits to total assets and EQUITY is the ratio of total equity to total assets. AFFECTED is a dummy is equal to 1 when the bank is a Dutch bank and 0 otherwise. POSTEVENT is a dummy equal to 1 for the years 2003 to 2006 and 0 otherwise. The model is estimated using OLS. The effect of LBR is captured by the coefficient on the interaction term Affected $\times$ PostEvent. ${ }^{*}, * *, * * *$ indicate significance at the $10 \%, 5 \%$, and $1 \%$ levels, respectively.

Table 9. Robustness analysis and sensitivity tests

\begin{tabular}{|c|c|c|c|c|c|c|c|c|c|}
\hline & & \multicolumn{4}{|c|}{ Panel 1. Broad sample of banks } & \multicolumn{4}{|c|}{ Panel 2. Subsample of listed banks } \\
\hline & & ZSCORE & Z1SCORE & Z2SCORE & SDROA & SDRETURN & BETA & IVOL & MZSCORE \\
\hline (1) & 4 Year rolling window & $\begin{array}{c}0.362^{* * *} \\
(0.105)\end{array}$ & $\begin{array}{c}0.442 \\
(0.572)\end{array}$ & $\begin{array}{c}0.335^{* * *} \\
(0.104)\end{array}$ & $\begin{array}{c}-0.556^{* *} \\
(0.209)\end{array}$ & & & & \\
\hline (2) & 5 Year rolling window & $\begin{array}{c}0.345^{* *} \\
(0.130)\end{array}$ & $\begin{array}{c}0.337 \\
(0.502)\end{array}$ & $\begin{array}{c}0.339 * * \\
(0.135)\end{array}$ & $\begin{array}{c}-0.498^{* *} \\
(0.187)\end{array}$ & & & & \\
\hline (3) & Last 3 months & & & & & $\begin{array}{c}-0.263^{* *} \\
(0.099)\end{array}$ & $\begin{array}{l}-0.934 \\
(1.394)\end{array}$ & $\begin{array}{c}-0.255^{* *} \\
(0.112)\end{array}$ & $\begin{array}{c}0.319^{* *} \\
(0.124)\end{array}$ \\
\hline (4) & Alternative matching & $\begin{array}{c}0.305^{* *} \\
(0.116)\end{array}$ & $\begin{array}{c}0.571 \\
(0.738)\end{array}$ & $\begin{array}{c}0.296 * * \\
(0.119)\end{array}$ & $\begin{array}{c}-0.356^{* *} \\
(0.133)\end{array}$ & $\begin{array}{c}-0.262 * * \\
(0.094)\end{array}$ & $\begin{array}{l}-0.522 \\
(0.771)\end{array}$ & $\begin{array}{c}-0.244^{* *} \\
(0.091)\end{array}$ & $\begin{array}{c}0.262^{* *} \\
(0.098)\end{array}$ \\
\hline (5) & 1 neighbor & $\begin{array}{c}0.451^{* * *} \\
(0.115)\end{array}$ & $\begin{array}{c}0.618 \\
(0.824)\end{array}$ & $\begin{array}{c}0.413 * * * \\
(0.113)\end{array}$ & $\begin{array}{c}-0.832^{*} \\
(0.498)\end{array}$ & & & & \\
\hline (6) & 5 neighbors & $\begin{array}{c}0.484^{* *} \\
(0.181)\end{array}$ & $\begin{array}{c}0.462 \\
(0.689)\end{array}$ & $\begin{array}{c}0.472^{* *} \\
(0.173)\end{array}$ & $\begin{array}{c}-0.547^{* *} \\
(0.204)\end{array}$ & & & & \\
\hline (7) & Benelux only & $\begin{array}{l}0.305^{* *} \\
(0.113)\end{array}$ & $\begin{array}{c}0.562 \\
(0.837)\end{array}$ & $\begin{array}{l}0.296^{* *} \\
(0.119)\end{array}$ & $\begin{array}{c}-0.356^{* *} \\
(0.133)\end{array}$ & & & & \\
\hline (8) & Belgium only & $\begin{array}{l}0.532^{* *} \\
(0.201)\end{array}$ & $\begin{array}{c}0.320 \\
(0.468)\end{array}$ & $\begin{array}{c}0.476^{* *} \\
(0.179)\end{array}$ & $\begin{array}{c}-0.687^{* * *} \\
(0.157)\end{array}$ & & & & \\
\hline (9) & Placebo test & $\begin{array}{c}0.193 \\
(0.264)\end{array}$ & $\begin{array}{c}0.647 \\
(0.766)\end{array}$ & $\begin{array}{c}0.176 \\
(0.264)\end{array}$ & $\begin{array}{l}-0.539 \\
(0.751)\end{array}$ & $\begin{array}{l}-0.157 \\
(0.175)\end{array}$ & $\begin{array}{l}-0.021 \\
(0.024)\end{array}$ & $\begin{array}{l}-0.190 \\
(0.213)\end{array}$ & $\begin{array}{c}0.162 \\
(0.182)\end{array}$ \\
\hline
\end{tabular}

Notes: The table presents the sensitivity of the baseline model to variations in the definition of the outcome variable, the sample size and matching procedure as well as false timing of the introduction of the LBR. For brevity, we only report the 
estimated coefficients of the variable of interest Affected $\times$ Post Event. The bank- and country-level controls as well as fixed effects are identical to those in Table 6. In rows (1) and (2), ZSCORE, Z1SCORE, Z2SCORE and SDROA are measured using a four-year rolling and five-year rolling window. Row (3) uses the last three months of the year to compute SDRETURN, BETA, IVOL and MZSCORE. Row (4) use alternative variables for the matching procedure. Instead of the growth rate in ZSCORE and MZSCORE, the growth rates of SDROA and SDRETURN is used. Row (5) and (6) match each Dutch bank with one and five unaffected banks, respectively. Rows (7) and (8) restrict the number of countries from which banks in the control group are selected to Benelux (i.e., Belgium and Luxembourg) and Belgium, respectively. Row (9) conducts a placebo test by falsely assuming the LBR was implemented in 2001 rather than 2003. *,**,*** indicate significance at the $10 \%, 5 \%$, and $1 \%$ levels, respectively. 